\title{
Control of Postharvest Crown Rot Disease in Cavendish Banana with Aluminium Sulfate and Vacuum Packaging
}

\author{
H. Siriwardana ${ }^{1}$, K. Abeywickrama ${ }^{1 *}$, S. Kannangara ${ }^{1}$ and B. Jayawardena ${ }^{2}$ \\ Received: $16^{\text {th }}$ January 2017 / Accepted: $21^{\text {st }}$ February 2017
}

\begin{abstract}
Effect of alum in combination with vacuum packaging was investigated in controlling crown rot disease of Cavendish banana (Musa acuminata, AAA, Grande Naine cultivar) at $12-14^{\circ} \mathrm{C}$. Twelve week mature Cavendish banana fruits were treated with $1 \%(w / v)$ alum (Potassium aluminium sulphate), $0.5 \mathrm{~g} / \mathrm{L}$ carbendazim (Positive control) or distilled water (Negative control). Treated banana samples were packed in Low Density Polyethylene bags(150 gauge) and stored at 12-14 ${ }^{\circ} \mathrm{C}$. In-package gases were analysed every seven days up to 28 days of storage.Physicochemical properties ( $\mathrm{pH}$, firmness, TSS, TA), sensory properties (peel colour, flesh colour, aroma, flavour, taste, overall acceptability) and crown rot disease severity were determined in ripening induced fruits after each storage period. Data obtained for physicochemical properties and in-package gases were subjected to ANOVA whereas pathological and sensory properties were analysed using Kruskal-Wallis non-parametric statistical test using Minitab. At the end of 28 days of storage, $\mathrm{O}_{2}$ in all packages remained between 5.6-5.8\% while $\mathrm{CO}_{2}$ remained between 5.0 to $5.1 \%$. Further, treatment of $1 \%$ alum alone controlled crown rot disease completely up to 14 days. Most of physicochemical and sensory properties of treated banana were not adversely affected by the treatment.
\end{abstract}

Keywords: Crown rot disease, in-package gases, physicochemical, sensory

\section{INTRODUCTION}

Cavendish, a worldwide cultivated commercial subgroup of banana, grown especially for export market, is a pure triploid of Musa acuminata (AAA) and its cultivars include, Lacatan, Poyo, Williams, Grand Naine, and Petite Naine (Aurore et al.,2009).

Crown rot disease of banana is a serious postharvest disease reducing the storage life which greatly influences export of banana. This disease is caused by a range of different fungi that occur on banana crop debris, including Colletotrichum musae, Lasiodiplodia theobromae as well as Fusarium spp., Verticillium spp. and Cephalosporium spp. (AbdAlla et al., 2014). These fungi penetrate directly into the tissues through wounds occurring in the 'dehanding' process and through contaminated

water used for washing bananas, which may serve as main source of fungal spores (Hailu et al., 2013).

Chemical control using fungicides such as carbendazim, methyl thiophanate, Imazalil and bitertanol is still the most common practice in controlling crown rot disease of banana. An abundance of fungicides are used in banana industry in major Cavendish banana exporting countries in Latin America, Caribbean, Far East and Africa irrespective of its hazardous effects on humans and environment (Lassois and Bellaire, 2014).

However, inorganically grown bananas, wound healing is the key point in preventing crown rot, because fungicide dips are not allowed. Latex 
exudates from the wounds form dark stains, which results in an unattractive appearance of fruits. To prevent this, $1-2 \%$ of alum is added to 'delatexing' tanks. Adding of alum helps to remove the latex, controls pathogens in the wash water and promotes the proper healing of the wound at crown (Anyasi et al., 2013).

Alum (Potassium Aluminum Sulfate), double sulfate with the formula of $\mathrm{KAl}\left(\mathrm{SO}_{4}\right)_{2} \cdot 12 \mathrm{H}_{2} \mathrm{O}$, is generally an odourless, colourless crystalline solid that turn white in air, which is used as an astringent and antiseptic in various food preparation processes such as pickling and fermentation and as a flocculent for water purification (Clark, 1970). Alum is added in the form of $\mathrm{KAl}\left(\mathrm{SO}_{4}\right)_{2} \cdot 12 \mathrm{H}_{2} \mathrm{O}$, which constitutes of tri-valent aluminium $\left(\mathrm{Al}^{3+}\right)$ in the treatment solution.Tri-valent aluminium is known to coagulate colloidal organic impurities in drinking water, either by forming soluble complexes at $\mathrm{pH}$ less than 4.5 or by the adsorption on aluminium hydroxide crystals formed at $\mathrm{pH}$ of 5 to 7 . In treatment of low turbidity drinking water, alum is used at concentrations of up to $2 \mathrm{ppm} \mathrm{Al}^{3+}$. A solution of $12 \mathrm{ppm} \mathrm{Al}^{3+}$, as used in Philippines in de-handing and flotation tanks, would be expected to assist in the coagulation of banana sap (Speiser and Berge, 2014). Food and Drug Administration (FDA) has recommended alum as category I active ingredient in mouthwashes (Olmez et al., 1998). Potassium Aluminum Sulfate solution has also been used to prolong shelf-life of tomatoes (Cemanes and Gabornes, 2013). Petrovsky and Aguilar (2004) reported on the use of alum as an adjuvant in the production of numerous vaccines including diphtheriatetanus-pertussis, human papillomavirus and hepatitis vaccines.

However, to the best of our knowledge, there are no reports on the effect of alum as a sole source in controlling crown rot disease of Cavendish banana. Therefore, this research was conducted to identify the efficacy of alum in controlling crown rot disease and extending shelf life of Cavendish banana which were subjected to vacuum packaging and stored at $12-14{ }^{\circ} \mathrm{C}$ up to one month. We aimed to examine headspace respiratory gas composition and crown rot disease severity and to evaluate physicochemical and sensory properties of alum treated Cavendish banana, which were subjected to packaging and storage as above.

\section{MATERIALS AND METHODS}

\section{Fruit harvesting, packaging and storage}

Twelve week mature Cavendish banana (Grande Naine cultivar) bunches were harvested from CIC banana plantation in Pelwehera, Dambulla, Sri Lanka. Banana bunches were transported to the CIC banana pack house, in CIC Agri Business Centre, Dambulla, Sri Lanka. Bunches were 'dehanded'and approximately $1 \mathrm{~kg}$ hands were selected as experimental units. All hands were washed in water to remove dirt and then washed with potassium aluminium sulphate (alum) $(1 \% \mathrm{w} / \mathrm{v})$ except control. A fungicide treatment of carbendazim $\left(0.5 \mathrm{~g} \mathrm{~L}^{-1}\right)$ and distilled water control were also included as positive and negative controls respectively. Banana hands were allowed to drip dry and placed separately in low density polyethylene (LDPE) bags ( 0.076 $\mathrm{mm}$ thickness) of $31.5 \times 32 \mathrm{~cm}$ surface area and polyethylene foam liners were placed on top of banana to provide protection to fruits. Air inside the bags was removed using a vacuum cleaner and mouths of bags were tied tightly with rubber bands and packed in $\left(40 \times 29 \times 19 \mathrm{~cm}^{3}\right)$ ventilated 3-ply fiberboard cartons. Each treatment comprised of four replicate boxes, each with five hands (weighing $5.0-5.5 \mathrm{~kg}$ ). All treatments were stored at $12-14{ }^{\circ} \mathrm{C}$ in a cold room at 85 90\% relative humidity at CIC Agri Business Centre, Dambulla, Sri Lanka (Abeywickrama et al., 2009). Observations were made after 7, 14, 21 and 28 days of storage. The experimental arrangement was a completely randomized design (CRD). This experiment was repeated once under identical conditions. 


\section{In-package gas analysis}

In-package respiratory gas $\left(\mathrm{O}_{2}\right.$ and $\left.\mathrm{CO}_{2}\right)$ variations within bags were measured on $7^{\text {th }}$, $14^{\text {th }}, 21^{\text {st }}$ and $28^{\text {th }}$ days during cold storage using a Digital Oxygen and Carbon Dioxide Head Space Gas analyzer (Model 902 D, Quantek Instruments, Grafton, MA). A needle was inserted into each bag and a small sample of package headspace gas was pumped into the gas analyzer and recorded the oxygen and carbon dioxide measurements (Kudachikar et al., 2011). Five replicate measurements were taken per treatment.

\section{Ripening of banana}

After each storage period, banana hands were subjected to induced ripening by exposure to ethylene (thrill $-480 \mathrm{~g} / \mathrm{L}$ ethephon, $1 \mathrm{~mL} / \mathrm{L}$ of water) for 24-48 $\mathrm{h}$ at ambient temperature of 26 $\pm 2{ }^{\circ} \mathrm{C}$ (Siriwardana et al., 2016).

\section{Pathological properties}

Crown rot in each hand was recorded using a standard index developed at the Department of Botany, University of Kelaniya (Crown Rot Severity (CRS) $0=$ No rot, $1=25 \%$ Crown rot, $2=50 \%$ Crown rot, $3=75 \%$ Crown rot, $4=100 \%$ Crown rot) (Abeywickrama et al., 2009; Siriwardana et al., 2016).

\section{Physicochemical properties}

Ten randomly selected fingers from each treatment were analyzed for physicochemical properties.

Total Soluble Solids (TSS): A $10 \mathrm{~g}$ sample of pulp from the middle of the fingers of banana was homogenized with $40 \mathrm{~mL}$ of distilled water in a blender (Black \& Decker, BX 250, Hunt Valley, USA) for $2 \mathrm{~min}$. The homogenate was filtered and the filtrate was taken to measure the TSS using a hand-held Refractometer (ATC, ATAGO, Japan, Brix; 0-32\%). The actual TSS content was calculated by multiplying each reading with the dilution factor (Abeywickrama et al., 2009; Siriwardana et al., 2016).Ten replicate samples were used per treatment.

$p H: \mathrm{pH}$ of the filtrates was measured using a digital $\mathrm{pH}$ meter (PC 510, EUTECH Instruments, Singapore). Ten replicate samples were used per treatment (Abeywickrama et al., 2009; Siriwardana et al., 2016).

Titratable Acidity (TA) (\% acid):Ten (10) $\mathrm{mL}$ samples from filtrates prepared for the TSS test were diluted with $20 \mathrm{~mL}$ distilled water and titrated against $0.1 \mathrm{M} \mathrm{NaOH}$ with phenolphthalein as the $\mathrm{pH}$ indicator. The end point was taken as the sudden appearance of slight pink colour in the solution. TA was calculated by multiplying the $\mathrm{NaOH}$ volume with the dilution factor and the malic acid factor (malic acid factor $=0.0067 \mathrm{~g}$ ).TA was expressed as \% malic acid (Abeywickrama et al., 2009; Siriwardana et al., 2016). Ten replicate samples were used per treatment.

Firmness: Fruit firmness of the pulp was measured using a Fruit Firmness Tester (FT 011, QA Supplies, Italy). The probe was gently pressed against a cross cut section $(1 \mathrm{~cm}$ thickness) of a finger until it indicated a constant value (Abeywickrama et al.,2009; Siriwardana et al., 2016). Ten replicate samples were used per treatment.

\section{Sensory properties}

Peel colour, flesh colour, flavour, taste, aroma, texture and overall acceptability of fruits were assessed by a trained ten member sensory panel. Each quality parameter was scored as follows: Excellent $=9-10$, Good $=6-8$, Fair $=4-5$, Poor $=1-3$ (Abeywickrama et al., 2009; Siriwardana et al., 2016).

\section{Statistical analysis}

Data obtained for in-package gases and physicochemical properties were subjected to ANOVA and mean separation was done using Tukey's Multiple Comparison test using Minitab. Data obtained for pathological and 
sensory properties were analysed using KruskalWallis non-parametric statistical test.

\section{RESULTS AND DISCUSSION}

\section{In-package gas analysis}

Oxygen level in all treated and control samples slightly decreased through 28 day storage period and final $\mathrm{O}_{2}$ levels were between 5.6$5.8 \%$ (Fig. 01.). Carbon dioxide level of alum treated banana increased slightly through the test period. However, in fungicide treated and control samples, gas levels increased slightly up to day 21 and thereafter remained more or less constant and final $\mathrm{CO}_{2}$ levels were within the range of 5.0-5.1\% (Figure 01). There was no significant difference of gas levels between treatments and the control.

The net extension in shelf life can be attributed to the overall low $\mathrm{O}_{2}$ retention that prevailed through the storage of vacuum packed samples. This modification in the gas composition by vacuum packaging reduces the fruit respiratory intensity and hampers endogenous ethylene production, which can considerably increase the length of the preclimacteric phase. Low $\mathrm{O}_{2}$ may also inhibit the metabolism of some pathogenic agents that can survive on the crown of banana.

In vacuum packaged banana (cv. Pachbale) stored at $13 \pm 1^{\circ} \mathrm{C}$ for 21 days, $\mathrm{O}_{2}$ concentrations were between $2-4 \%$ while $\mathrm{CO}_{2}$ ranged between
4-6\% (Chauhan et al., 2006). Abdulla et al., (1993) reported that banana cv. Berangan packed in polyethylene bags with or without ethylene absorbent maintained the levels of $\mathrm{CO}_{2}$ and $\mathrm{O}_{2}$ around $3.4 \%-6.7 \%$ and $1.6 \%-6.1 \%$, respectively from first to fourth week of storage at $14{ }^{\circ} \mathrm{C}$. These findings are in accordance with the current research data.

\section{Pathological properties}

Alum treatment showed no crown rot disease up to 14 days, but, showed mild crown rot disease (CRS $=0.3 ; 7.5 \%$ crown rot) after 21 days (Figure 02). Fungicide treatment also showed similar crown rot disease severity on day 21. Control banana showed higher crown rot disease severity in all analysis days compared to other treatments, with the highest mean crown rot disease severity of 1.7 (42.5\% crown rot) on day 21.Crown rot disease severity of alum and fungicide treated banana was significantly low compared to the control $(\mathrm{P}<0.05)$.

In agreement with the present results, Abeywickrama et al., (2009) reported that, 1\% alum washed and vacuum packed Embul banana showed lower crown rot disease compared to control samples in cold storage at $13-15{ }^{\circ} \mathrm{C}$. Alum at $1 \%(\mathrm{w} / \mathrm{v})$ prevented mycelial growth of crown rot pathogen $L$. theobromae and papaya stem end rot pathogen Phomopsis caricaepapayae during in vitro assay (Abeywickrama et al., 2012).

B

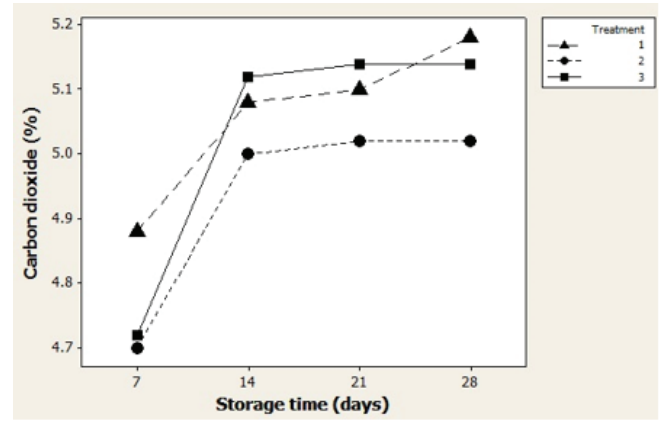

Figure 01: Oxygen (A) and Carbon dioxide (B) gas concentrations of vacuum packaged Cavendish banana(Treatment: 1 - 1\% alum, 2- $0.5 \mathrm{~g} \mathrm{~L}^{-1}$ carbendazim 3- control) 


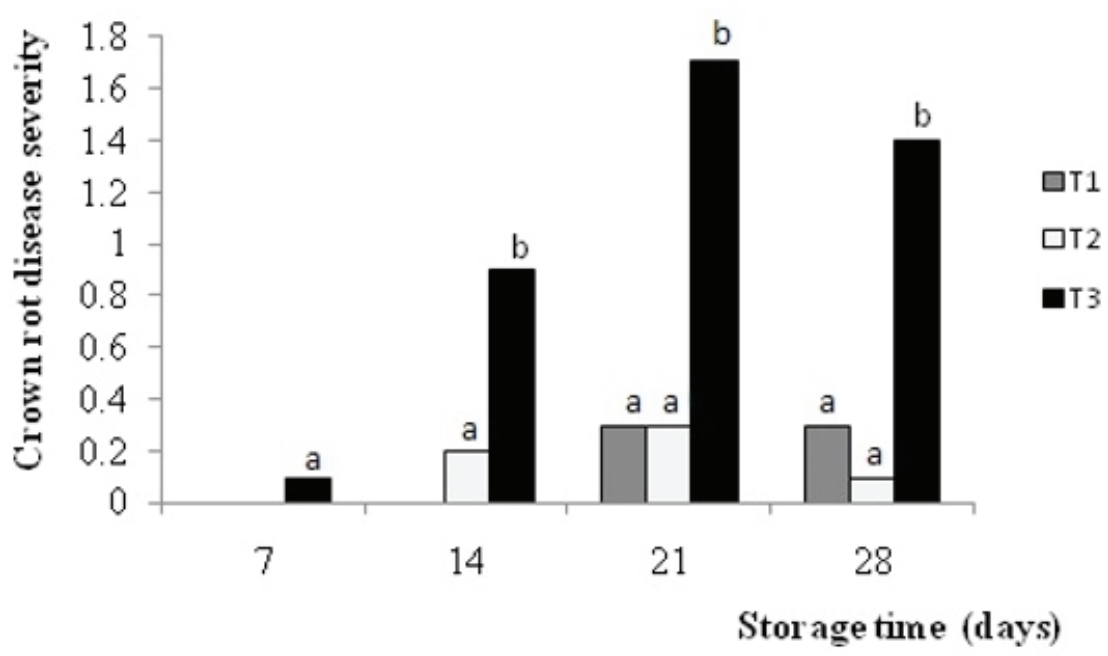

Figure 02: Crown rot disease severity of vacuum packaged Cavendish banana treated with $1 \%$ alum (T1), $0.5 \mathrm{~g} \mathrm{~L}^{-1}$ carbendazim (T2) and distilled water (T3) after each storage period at $12-14{ }^{\circ} \mathrm{C}$ and subjected to induced ripening.

Each data point represents the mean of ten replicates.

Bestoon (2012) reported on the antibacterial action of alum solution $(1 \mathrm{mg} / \mathrm{mL}$, at $\mathrm{pH}$ 3.6) against bacterial isolates found in infected root canals, including facultative anaerobic microorganisms (Escherichia coli, Staphylococcus aureus and Klebsiella sp.), and aerobic species (Pseudomonus aeruginosa), using agar well diffusion test. Alum solution was able to demonstrate antibacterial activity against all the bacteria tested, and produced inhibition zones of 27, 25, 24 and $22 \mathrm{~mm}$ against $S$. aureus, P. aerogenosa, E.coli and Klebsiella sp. respectively.

Bnyan (2014) tested different concentrations of alum (10, 20, 30, 40 and 50) w/v \% against four bacterial isolates (S. aureus, $S$. epidermidis, E. coli, Klebsiella pneumonia) and the results showed that the $20 \%$ of alum was found to be Minimum Inhibitory. Also, from the results, it was observed that the bacterial growth inhibition was increased when the alum concentration increased. Exact action of alum on crown rot disease control is not known. However, mechanism of action of alum against microorganisms would be due to the competition for nutrients and sites in the wound so the pathogen is unable to grow.

\section{Physicochemical properties}

TSS: During the current research, TSS decreased up to $14^{\text {th }}$ day and then increased in all treatments and in the control. Higher TSS values were reported for control samples over alum and fungicide treated samples except on day 7. Total Soluble Solid values ranged from 15.50 to 20.80 ( ${ }^{\circ}$ Brix) during the 28-day storage period (Table 01.). Further, TSS values of alum treated banana were not statistically significant, compared to the control except on day 7 .

During banana ripening, sugars increase as starch is converted to soluble solids, of which sucrose comprised more than $70 \%$ of the total sugars in fully ripe banana, followed by glucose and fructose (Marriott et al., 2006). Total Soluble Solids (TSS) is an important measure related to consumer taste preference and fruits above $12 \%$ Brix are considered more acceptable to consumers (Mcglone and Kawano, 1998). According to Opara et al., (2013) TSS of ripe Dwarf Cavendish banana were within 19.6 - 
21.2 ${ }^{0}$ Brix while $14.00{ }^{0}$ Brix was reported for TSS of Grande Naine banana (Dadzie, 1998). Results obtained during current research are compatible with previously published literature.

$p H: \mathrm{pH}$ values of all treated and control samples dropped over time except in alum treated samples on day 28 and the values ranged from 4.65-4.93 (Table 01). $\mathrm{pH}$ values of alum treated Cavendish banana were not significantly different compared to the control in each analysis day, except on day 21 .

$\mathrm{pH}$ is high in mature green banana and gradually decreased with ripening. $\mathrm{pH}$ of the pulp of the green banana fruit ranged between $5-5.8$ while $\mathrm{pH}$ of the pulp of ripened banana fruit ranged between 4.2 - 4.8 (Hailu et al., 2013). Marin et al.,(1996) reported, $\mathrm{pH}$ of Grande Naine (AAA) banana after ripening were in the range of 4.944.95 while, Opara et al., (2013) reported $\mathrm{pH}$ of Dwarf Cavendish banana were to be in the range of 4.98-5.43. According to Dadzie (1998), $\mathrm{pH}$ of Grande Naine banana after ripening attained a value of 4.93.Therefore, current results are in agreement with the previous literature.

TA: There were slight variations of titratable acidity over time and values ranged from 0.65 to 0.77 (\% Malic acid) (Table 01.).TA values of alum and fungicide treated banana were not significantly different, compared to the control. With ripening of banana, TA increases causing a drop in the $\mathrm{pH}$. According to Dadzie (1998), TA of Grande Naine banana was about $0.30 \%$ Malic acid after ripening while Opara et al., (2013) reported TA values in Dwarf Cavendish banana to be in the range of $0.34-0.41 \%$ Malic acid. Current results are higher than previous literature reports indicating higher acidity of samples.
Firmness: Firmness values of samples ranged from 0.39 to $0.47\left(\mathrm{~kg} \mathrm{~cm}^{-2}\right)$ in all treatments and in the control (Table 01.). Although there were slight variations of firmness over time, by day 28 firmness values decreased. Lowest firmness was seen in the control sample while alum treated banana showed highest firmness on day 28 (Table 01.). Firmness values in all treated and in the control banana were not significantly different.

During ripening of banana, firmness decreased to a relatively narrow optimal eating range of $0.7-0.4 \mathrm{~kg} \mathrm{~cm}^{-2}$ beyond which the fruit becomes senescent. This decrease in firmness is due to solubilization of peptic substances in the cell wall and middle lamella (Dadzie, 1998). In accordance with the current results, Opara et al., (2013) reported that fruit firmness of Dwarf Cavendish banana gradually decreased over 21day storage period at $11-12^{\circ} \mathrm{C}$.

\section{Sensory properties}

Sensory panelists preferred the alum treated banana over the fungicide treated and the control banana after 28 days of storage which were subjected to induce ripening. Score values obtained for alum treated Cavendish banana were 6 or above indicating samples were of 'good' quality (Table 02.).There was no significant difference of sensory properties of alum treated banana, except for flavour and taste compared to the control. Similarly, Abeywickrama et al., (2009) reported that sensory properties of $1 \%$ alum washed and vacuum packed Embul banana were slightly affected compared to untreated fruits. 
Table 01: Physicochemical properties of vacuum packaged Cavendish banana stored at $12-14{ }^{\circ} \mathrm{C}$ after induced ripening.

\begin{tabular}{ccccc}
\hline \multirow{2}{*}{ Treatment } & \multicolumn{5}{c}{ Storage time } \\
\cline { 2 - 5 } & day 7 & day 14 & day 21 & day 28 \\
\hline \multicolumn{5}{c}{$\mathrm{pH}$} \\
\hline T1 & $4.93^{\mathrm{a}} \pm 0.04$ & $4.85^{\mathrm{a}} \pm 0.04$ & $4.65^{\mathrm{a}} \pm 0.03$ & $4.78^{\mathrm{a}} \pm 0.05$ \\
T2 & $4.91^{\mathrm{a}} \pm 0.06$ & $4.88^{\mathrm{a}} \pm 0.00$ & $4.78^{\mathrm{a}} \pm 0.02$ & $4.74^{\mathrm{a}} \pm 0.01$ \\
T3 & $4.86^{\mathrm{a}} \pm 0.02$ & $4.88^{\mathrm{a}} \pm 0.03$ & $4.74^{\mathrm{b}} \pm 0.03$ & $4.73^{\mathrm{a}} \pm 0.04$ \\
\hline \multicolumn{5}{c}{ TSS $\left({ }^{0} \mathrm{Brix}\right)$} \\
\hline T1 & $20.80^{\mathrm{a}} \pm 0.48$ & $15.80^{\mathrm{a}} \pm 0.30$ & $17.30^{\mathrm{a}} \pm 0.58$ & $17.00^{\mathrm{a}} \pm 0.28$ \\
T2 & $17.80^{\mathrm{b}} \pm 0.20$ & $15.50^{\mathrm{a}} \pm 0.43$ & $17.40^{\mathrm{a}} \pm 0.40$ & $17.30^{\mathrm{a}} \pm 0.57$ \\
T3 & $18.50^{\mathrm{b}} \pm 0.48$ & $16.30^{\mathrm{a}} \pm 0.30$ & $17.90^{\mathrm{a}} \pm 0.34$ & $17.70^{\mathrm{a}} \pm 0.54$ \\
\hline \multicolumn{5}{c}{ Firmness $\left(\mathrm{kg} \mathrm{cm}^{-2}\right)$} \\
\hline T1 & $0.41^{\mathrm{a}} \pm 0.01$ & $0.44^{\mathrm{a}} \pm 0.00$ & $0.47^{\mathrm{a}} \pm 0.02$ \\
T2 & $0.43^{\mathrm{a}} \pm 0.02$ & $0.43^{\mathrm{a}} \pm 0.02$ & $0.47^{\mathrm{a}} \pm 0.02$ & $0.43^{\mathrm{a}} \pm 0.01$ \\
T3 & $0.39^{\mathrm{a}} \pm 0.01$ & $0.43^{\mathrm{a}} \pm 0.01$ & $0.44^{\mathrm{a}} \pm 0.02$ & $0.41^{\mathrm{a}} \pm 0.00$ \\
\hline \multicolumn{5}{c}{ TA $(\%$ Malic acid $)$} \\
\hline T1 & $0.72^{\mathrm{a}} \pm 0.03$ & 0.00 \\
\hline T2 & $0.73^{\mathrm{a}} \pm 0.03$ & $0.62^{\mathrm{a}} \pm 0.04$ & $0.77^{\mathrm{a}} \pm 0.04$ \\
T3 & $0.75^{\mathrm{a}} \pm 0.03$ & $0.67^{\mathrm{a}} \pm 0.01$ & $0.75^{\mathrm{a}} \pm 0.04$ & $0.70^{\mathrm{a}} \pm 0.04$ \\
\hline
\end{tabular}

$\mathrm{T} 1$ - $1 \%$ alum, T2- $0.5 \mathrm{~g} \mathrm{~L}^{-1}$ carbendazim, T3- control.

*Each data point represents the mean of ten replicates \pm standard error.

*Means sharing a common letter (s) in each column are not significantly different by Tukey's multiple comparison test.

Table 02: Sensory scores obtained for treatments stored for 14 days at $12-14{ }^{\circ} \mathrm{C}$ after induced ripening from sensory panel at University of Kelaniya.

\begin{tabular}{cccccccc}
\hline & \multicolumn{7}{c}{ Sensory property } \\
\cline { 2 - 7 } Treatment & Peel colour & Flesh colour & Flavour & Aroma & Taste & Texture & $\begin{array}{c}\text { Overall } \\
\text { acceptability }\end{array}$ \\
\hline $1 \%$ alum & $6.7^{\mathrm{a}}$ & $7.0^{\mathrm{a}}$ & $7.3^{\mathrm{a}}$ & $6.9^{\mathrm{a}}$ & $7.6^{\mathrm{a}}$ & $7.1^{\mathrm{a}}$ & $7.1^{\mathrm{a}}$ \\
$1 \%$ alum & $6.6^{\mathrm{a}}$ & $6.8^{\mathrm{a}}$ & $6.3^{\mathrm{b}}$ & $6.7^{\mathrm{a}}$ & $6.2^{\mathrm{b}}$ & $6.5^{\mathrm{a}}$ & $6.4^{\mathrm{a}}$ \\
control & $6.7^{\mathrm{a}}$ & $6.9^{\mathrm{a}}$ & $6.1^{\mathrm{b}}$ & $5.9^{\mathrm{a}}$ & $5.8^{\mathrm{b}}$ & $6.1^{\mathrm{a}}$ & $6.2^{\mathrm{a}}$ \\
\hline
\end{tabular}

*Each data point represents the mean of twenty replicates.

(Excellent 9-10, Good 6-8, Fair 4-5, Poor 1-3).

*Means sharing a common letter (s) in each sensory property are not significantly different by Kruskal Wallies non parametric statistical test.

\section{CONCLUSIONS}

Alum treatment combined with vacuum packaging controlled crown rot disease of Cavendish banana completely up to two weeks in cold storage. Most of the physicochemical and sensory properties of treated samples were not significantly different compared to the control samples, although with slight variations. Alum treated samples were preferred by sensory panelists than the other treatments. Vacuum packaging of banana does not involve application of any potentially toxic chemical but only involves washing with alum (potassium 
aluminum sulfate) solution. This treatment of alum combined with vacuum packaging is a relatively cost effective technology, which could be used in organic banana industry where fungicides are not allowed in sea shipments or air freight where two weeks of transit time is required.

\section{ACKNOWLEDGEMENTS}

Financial assistance provided by the National Research Council (NRC), Grant 12-003, Sri Lanka is highly appreciated.

\section{REFERENCES}

Abd-Alla, M.A., El-Gamal, N.G., El-Mougy, N.S. and Abdel-Kader, M.M. (2014). Post-harvest treatments for controlling crown rot disease of Williams banana fruits (Musa acuminata L.) in Egypt. Plant Pathology and Quarantine. 4 (1): 1-12. DOI: 10.5943/ppq/4/1/1. DOI: http://dx.doi.org/10.2478/v10045-010-0079-0

Abeywickrama, K., Wijerathna, C., Herath, H. and Sarananda, K. (2009). An integrated treatment of basil oil (Ocimum basilicum) and alum with modified atmosphere to control crown rot disease in Embul banana. Tropical Agricultural Research and Extension. 12: 23-30. DOI: http://dx.doi.org/10.4038/tare.v12i1.1980

Abeywickrama, K., Wijerathna, C., Rajapaksha, N., Sarananda, K. and Kannangara, S. (2012). Disease control strategies for extending storage life of papaya (Carica papaya), cultivars 'Red Lady' and 'Rathna'. Ceylon Journal of Science. 41(1): 27-34.doi:http://doi.org/10.4038/ cjsbs.v41i1.4535. DOI: http://dx.doi.org/10.4038/cjsbs.v41i1.4535

Abdullah, H., Rohaya, M.A. and Yunus, J.M. (1993). Effects of precooling, ethylene absorbent and partial evacuation of air on storage of banana (Musa sp. cv. Berangan) under modified atmosphere. MARDI Research Journal. 21: 171-177. DOI: http://dx.doi.org/10.1111/j.17454549.2011.00583.x

Anyasi, T.A., Jideani, A.I.O. and Mchau, G.R.A. (2013). Functional properties and postharvest utilization of commercial and noncommercial banana cultivars. Comprehensive Reviews in Food Science and Food Safety. 12: 509-522. DOI: http://dx.doi.org/10.1111/15414337.12025

Aurore, G., Parfait, B. and Hrasmane, L. (2009). Bananas raw materials for making processed food products. Trends in Food Science Technology. 20(2): 78-91. DOI: http://dx.doi.org/10.1016/j. tifs.2008.10.003

Bestoon, M.F. (2012). Evidence for feasibility of aluminum potassium sulfate (alum) solution as a root canal irrigant. Journal of Baghdad College Dentistry. 24(1): 1-5. DOI: http://dx.doi. org/10.1038/sj.ebd.6400891

Bnyan, I.A. (2014). Antibacterial Activity of Aluminum Potassium Sulfate and Syzygium Aromaticum Extract Against Pathogenic Microorganisms. Journal of Natural Sciences Research. 4(15): 11-14. DOI: http://dx.doi.org/10.9734/bjpr/2014/10925 
Cemanes, M. and Gabornes, P. (2013). Firming and shelf life of tomatoes as affected by alum (Tawas) and lime (Apog) treatment. Leyte National High School, Leyte, Philippines. DOI: http://dx.doi.org/10.2986/tren.090-0137

Chauhan, O.P., Raju, P.S., Dasgupta, D.K. and Bawa A.S. (2006). Instrumental Textural Changes in Banana (Var. Pachbale) During Ripening Under Active and Passive Modified Atmosphere. International Journal of Food Properties. 9: 237-253. DOI: http://dx.doi. org/10.1080/10942910600596282

Clark, J.D. (1970). North Carolina popular beliefs and superstitions. North Carolina Folklore. 18:1-66. DOI: http://dx.doi.org/10.2307/1498734

Dadzie, B.K. (1998). Post-harvest characteristics of black Sigatoka resistant banana, cooking banana and plantain hybrids. Inibap Technical Guidelines. International Plant Genetic Resources Institute, Rome, Italy. 34 pp. DOI: http://dx.doi.org/10.4314/as.v8i2.51109

Gutierrez Gonzales, G. (2013). Technical guide for the successful production of export bananas in Sudan.http://www.fao.org/fileadmin/templates/banana/documents/Docs/ Resources2015/ TR4/Technical.pdf. 07.06.2016. DOI: http://dx.doi.org/10.1215/9780822385288-003

Hailu, M., Workneh, T.S. and Belew, D. (2013). Review on postharvest technology of banana fruit. African Journal of Biotechnology. 12(7): 635-647.doi: 10.5897/AJBX12.020. DOI: http:// dx.doi.org/10.2212/spr.2013.3.6

Lassois, L. and Bellaire L.D.L.D. (2014). Crown rot disease of bananas. https:/orbi.ulg. ac.be/bitstream/2268/169795/1/lassois_postharvest_decay_2014_chap3_103-130.pdf. 01.03.2017. DOI: http://dx.doi.org/10.1016/b978-0-12-411552-1.00003-x

Marin, D.H., Blankenship, S.M., Sutton, T.B. and Swallow, W.H. (1996). Physiological and Chemical Changes during Ripening of Costa Rican Bananas Harvested in Different Seasons. Journal of the American Society for Horticultural Science. 121(6): 1157-1161. DOI: http:// dx.doi.org/10.1080/14620316.1998.11511017

Marriott, J., Robinson, M. and Simon, K. (2006). Starch and sugar transformation during the ripening of plantains and bananas. Journal of the Science of Food and Agriculture.32(10): 1021-1026. DOI: http://dx.doi.org/10.1002/jsfa.2740321011

McGlone, V.A. and Kawano, S. (1998). Firmness, dry matter and soluble solids assessment of postharvest kiwifruit by NIR spectroscopy. Postharvest Biology and Technology. 13: 131141.doi: 10.1016/s0925-5214(98)00007-6.

Kudachikar, V.B., Kulkarni, S.G. and Prakash, M.N.K. (2011). Effect of modified atmosphere packaging on quality and shelf life of 'Robusta' banana (Musa sp.) stored at low temperature. Journal of Food Science and Technology. 48(3): 319-324.doi: https://dx.doi. org/10.1007\%2Fs 13197-011-0238-y.

Olmez, A., Can, H., Ayhan, H. and Olur, H. (1998). Effect of alum containing mouth rinse in children for plaque and salivary levels of selected oral microflora. Journal of Clinical Pediatric Dentistry. 22: 335-41. DOI: http://dx.doi.org/10.2174/1874210601610010207 
Opara,U.L., Al-Yahyai, R., Al-Waili, N., Al-Said, F., Al-Ani, M., Manickavasagan, A. and Al-Mahdouri, A. (2013). Postharvest Responses of 'Malindi' Cavendish Banana to Various Storage Conditions. International Journal of Fruit Science. 13:373-388.doi: 10.1080/15538362.2013.748378. DOI: http://dx.doi.org/10.1080/15538362.2013.748378

Petrovsky, N. and Aguilar, J.C. (2004). Vaccine adjuvants: Current state and future trends. Immunology and Cell Biology. 82: 488-496.doi:10.1111/j.0818-9641.2004.01272.x.

Siriwardana, H., Abeywickrama, K., Kannangara, S. and Attanayake, S. (2016). Medium Scale Test Marketing Trials to Identify The Suitability of Basil Oil, Alum Plus Modified Atmosphere Packaging in Controlling Crown Rot Disease of Cavendish Banana. Annals of Food Science and Nutrition. 1(1): 1-8. DOI: http://dx.doi.org/10.1016/j.scienta.2017.01.032

Speiser, B. and Berge, P.V. D. (2014). Position paper on the use of potassium alum in organic banana production. Forschungsinstitut für biologischen Landbau (FiBL), Frick, Schweiz. http:// www.betriebsmittelliste.ch/fileadmin/documents/de/hifu/stellungnahmen/organic banana potassium alum dec_2014.pdf. 07.08.2016. DOI: http://dx.doi.org/10.3403/30308360 